\title{
CLINICAL STUDIES OF THE BLOOD VOLUME. VII. CHANGES IN BLOOD VOLUME IN BRIGHT'S DISEASE WITH OR WITHOUT EDEMA, RENAL INSUFFICIENCY, OR CONGESTIVE HEART FAILURE, AND IN HYPERTENSION ${ }^{1}$
}

\author{
BY ALFRED W. HARRIS AND JOHN G. GIBSON, 2D \\ (From the Medical Clinic of the Peter Bent Brigham Hospital and the Department of \\ Medicine, Harvard Medical School, Boston)
}

(Received for publication April 17, 1939)

Richard Bright (1) in 1836 remarked upon the watery condition of the blood in the edematous phase of disease of the kidneys and attributed it to a loss of albuminous substances into the urine with a resultant thinning of the blood. Since that time numerous investigators, aware of the rôle of the kidneys in the excretion of water and electrolytes and of the relation of the blood protein concentration to edema, have studied the water balance in Bright's disease, many with particular reference to the total amount of circulating blood and the changes in the plasma and total blood volume which occur during the edematous stage of renal disease and during diuresis.

The evaluation of the few reports in the literature on the state of the blood volume in Bright's disease is difficult because of the variety of methods of determining the plasma volume employed, the wide divergence in normal values obtained by these methods, and the lack of a consistent clinical classification of the cases of nephritis studied.

Several authors give no further description than that their cases had "renal edema." Thus Plesch (2) using a CO method and Schmidt (3) using a Congo Red dye method of determining the blood volume found total blood volume above normal, while Waterfield (4) using a CO method found it decreased, and Linder et al. (5) reported plasma volume as determined by a dye method to be normal in cases with " renal edema."

Hartwich and May (6) and Litzner (7), both of whom used dye methods, found a normal plasma but high blood volume, whereas Rusznyak (8) with a dye method found total blood volume

1 This study was aided by a grant from the Proctor Fund for the Study of Chronic Diseases, Harvard Medical School. to be subnormal due to a lowered red cell volume. In chronic glomerular nephritis Brown and Rowntree (9), using the original dye method, reported plasma volume to be normal and total blood volume decreased in 12 cases, but Hartwich and May (6) reported 6 cases with increased and 4 with decreased total blood volumes.

Darrow (10) reported 2 cases of " nephrosis" studied by a dye method with subnormal total blood volumes, while Brown and Rowntree (9) found total blood volume normal, if no anemia was present, and above normal in their anemic cases. Waterfield (4) stated that in the edematous stage of renal disease total blood volume was least when the amount of edema was greatest and rose during diuresis due to an increase in plasma volume, this latter finding being in agreement with that of Darrow (10). Brown and Rowntree (9) concluded that the mechanism of diuresis was different in chronic nephritis than in " nephrosis," since in the former condition total blood volume decreased, but no constant change in either plasma or red cell volume was observed in the latter during diuresis.

Rusznyak (8) reported very low total blood volume in 24 cases of " extra-renal" hypertension. He also made the interesting observation that only in a group of cases with " contracted kidneys" was the total blood volume ever greater than normal.

It is apparent that the available information concerning the state of the blood volume in hypertension and nephritis is of a contradictory nature, and we, therefore, considered it worth while to re-investigate the subject using a method (11) of determining the blood volume which we have found to minimize the effects of errors inherent in many of the techniques employed by the above authors. 


\section{MATERIALS STUDIED}

Cases studied were selected from the Medical Service and Out-Door Department of the Peter Bent Brigham Hospital. For analytical purposes Christian's (12) clinical classification of nephritis was used, patients having been divided into 5 groups as follows:

Group I: Seven males and 6 females with chronic glomerular nephritis without renal edema. Characteristic of this group was persistent albuminuria and cylindruria and varying degrees of anemia, hypertension, impaired renal excretion of phenolsulphonephthalein and blood nonprotein nitrogen retention.

Group II: Two males and 2 females with acute hemorrhagic nephritis. All of these cases had albuminuria, hematuria, and anemia.

Group III: Nine males and 1 female with subacute glomerular nephritis with renal edema (nephrosis syndrome). All of these cases had profuse albuminuria, doubly refractile lipoid bodies in their urine, high blood cholesterol, low basal metabolic rates, and varying degrees of elevation in systolic and diastolic blood pressure and of hypoproteinemia with distortion of the normal albumin-globulin ratio. In 6 of these cases the course of the blood volume was followed by repeated determinations during the course of diuresis.

Group IV: A mixed group, who presented in addition to renal disease with or without renal failure the common finding of congestive heart failure, consisting of 1 female with bilateral polycystic kidneys (Case 368), 1 male and 2 females with chronic glomerular nephritis (Cases 359, 380, and 403), and 1 male and 1 female with chronic vascular nephritis (Cases 393 and 374).

Group $V$ : Five males and 11 females with essential hypertension. In all cases systolic blood pressure was $160 \mathrm{~mm}$. of mercury or above, and in none was there evidence of renal insufficiency or congestive heart failure.

\section{METHODS}

Plasma, circulating red cell, and total blood volume were determined by the dye method of Gibson and Evans (11), venous pressure by the direct method of Evans (13), circulation time by the intravenous decholin method of Winternitz,
Deutsch, and Brüll (14), hemoglobin by the Osgood-Haskins modification of the method of Sahli (15), blood urea nitrogen by the urease method of Van Slyke and Cullen (16), protein and nonprotein nitrogen concentration by modifications of the methods of Folin (17) and Koch and McMeekin (18).

\section{RESULTS}

Height was taken as the basis for prediction of normal volume, since surface area as a basis would have given a distorted normal value in those patients who had extensive edema and in those who were cachectic in the non-edematous stages of their chronic disease.

Plasma, circulating red cell and total blood volume, blood chemistry, hematology, and hemodynamics in Groups I, II, III, and IV are shown in Table $I$ and the corresponding findings in Group $\mathrm{V}$ in Table II.

The distribution of cases in Groups I, III, and $\mathrm{V}$ in terms of percentage deviation from predicted normal plasma, circulating red cell and total blood volume is shown in Figure 1. The normal range of plasma, circulating red cell, or total blood volume may be considered to be plus or minus 15 per cent (19). The statistical method of determining the standards of normality employed in this study is such that the average values in terms of percentage deviation from normal for any group of individuals with essentially normal plasma and total blood volumes will closely approximate zero. Therefore, in abnormal groups, the averages of deviations from normal represent significant departures in plasma, circulating red cell, and total blood volume from the normal state characteristic of the common diseased state of the members of the group, even though the average values themselves may fall within the accepted range of normality. It is, therefore, evident from the average values that the hypertensives constitute a group with plasma, circulating red cell, and total blood volumes well within the range of normality. In Groups I and III total blood volume is definitely subnormal, more so in the latter than in the former groups, due to a great reduction in circulating red cell volume, which in both groups is considerable enough to more than offset a higher than normal plasma volume. 
TABLB I

Blood volume, hemodynamics, and blood chemistry in nephritis with and without renal edema and congestive heart failure

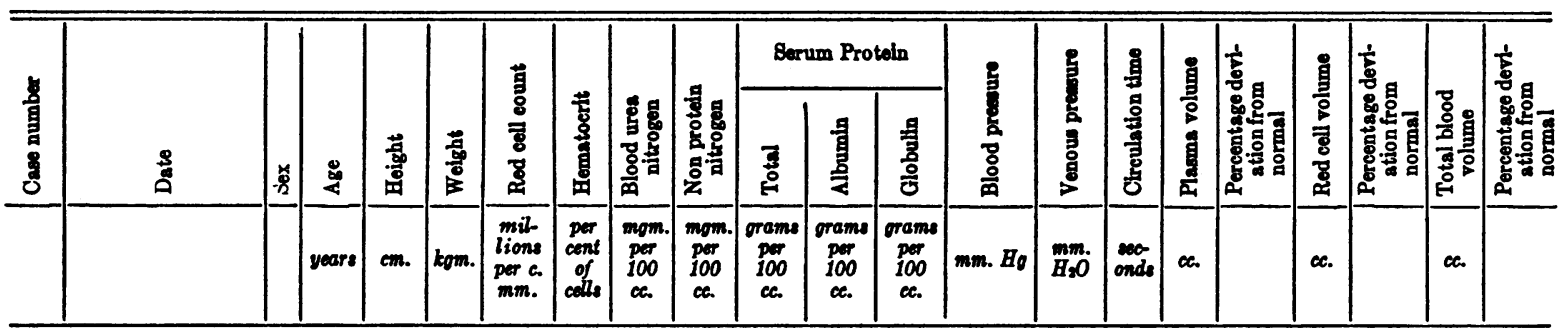

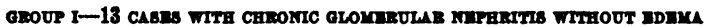

\begin{tabular}{|c|c|c|c|c|c|c|c|c|c|c|c|c|c|c|c|c|c|c|c|c|c|}
\hline $\begin{array}{l}\mathbf{3 5 7} \\
\mathbf{3 5 8} \\
\mathbf{3 6 1} \\
\mathbf{3 6 3} \\
\mathbf{3 6 6} \\
\mathbf{3 7 1} \\
\mathbf{3 7 2} \\
\mathbf{3 7 3} \\
\mathbf{3 7 5} \\
\mathbf{3 7 9} \\
\mathbf{3 9 2} \\
\mathbf{3 9 4} \\
\mathbf{4 0 4}\end{array}$ & $\begin{array}{l}\text { June 24, } 1938 \\
\text { June 25, } 1938 \\
\text { June 27, } 1938 \\
\text { June 28, } 1938 \\
\text { August 30, } 1938 \\
\text { September 13, } 1938 \\
\text { September 15, } 1938 \\
\text { September 19, } 1938 \\
\text { September 28, } 1938 \\
\text { October 3, 1938 } \\
\text { February 15, 1939 } \\
\text { Februsry 16, } 1939 \\
\text { March 7, 1939 }\end{array}$ & $\begin{array}{l}\mathrm{M} \\
\mathbf{F} \\
\mathrm{F} \\
\mathrm{M} \\
\mathrm{M} \\
\mathrm{M} \\
\mathrm{F} \\
\mathrm{M} \\
\mathrm{F} \\
\mathrm{F} \\
\mathrm{M} \\
\mathrm{F} \\
\mathrm{M}\end{array}$ & $\begin{array}{l}37 \\
20 \\
37 \\
22 \\
21 \\
28 \\
40 \\
27 \\
19 \\
26 \\
34 \\
43 \\
51\end{array}$ & $\begin{array}{l}165.0 \\
173.5 \\
154.5 \\
170.0 \\
175.3 \\
167.5 \\
162.5 \\
167.5 \\
162.5 \\
152.0 \\
185.0 \\
158.8 \\
169.4\end{array}$ & $\begin{array}{l}52.3 \\
60.0 \\
60.5 \\
65.2 \\
52.0 \\
52.5 \\
62.7 \\
52.5 \\
51.4 \\
55.9 \\
73.5 \\
72.8 \\
66.8\end{array}$ & $\begin{array}{l}4.01 \\
3.23 \\
4.40 \\
5.00 \\
3.12 \\
4.35 \\
2.57 \\
4.40 \\
4.32 \\
4.24 \\
3.45 \\
2.07 \\
3.58\end{array}$ & $\begin{array}{l}40.0 \\
27.4 \\
38.4 \\
48.8 \\
34.4 \\
34.2 \\
29.4 \\
42.6 \\
37.2 \\
42.1 \\
26.3 \\
17.7 \\
29.5\end{array}$ & $\begin{array}{l}27 \\
40 \\
29 \\
8 \\
50 \\
49 \\
39 \\
17 \\
10 \\
10 \\
61 \\
86 \\
39\end{array}$ & $\begin{array}{r}82 \\
57 \\
34 \\
\\
114 \\
125 \\
59\end{array}$ & $\begin{array}{l}\mathbf{5 . 5} \\
\mathbf{5 . 7} \\
\mathbf{6 . 1} \\
\mathbf{6 . 5} \\
\mathbf{6 . 0} \\
\mathbf{7 . 1} \\
\mathbf{5 . 6} \\
6.9 \\
\mathbf{7 . 7} \\
\mathbf{6 . 6} \\
\mathbf{6 . 6} \\
\mathbf{7 . 0} \\
\mathbf{5 . 5}\end{array}$ & $\begin{array}{l}3.2 \\
3.6 \\
2.7 \\
4.5 \\
3.4 \\
4.3 \\
3.1 \\
4.6 \\
4.6 \\
3.7 \\
4.5 \\
4.2 \\
3.4\end{array}$ & $\begin{array}{l}2.3 \\
2.1 \\
2.9 \\
2.0 \\
2.6 \\
2.8 \\
2.5 \\
2.3 \\
3.1 \\
2.9 \\
2.1 \\
2.8 \\
2.1\end{array}$ & $\begin{array}{l}156 / 112 \\
130 / 80 \\
150 / 106 \\
108 / 80 \\
140 / 90 \\
256 / 160 \\
160 / 100 \\
126 / 88 \\
124 / 85 \\
134 / 88 \\
220 / 130 \\
200 / 110 \\
140 / 70\end{array}$ & \begin{tabular}{|l|}
90 \\
110 \\
$150(?)$ \\
120 \\
80 \\
\\
\\
105 \\
$155(?)$ \\
45 \\
150
\end{tabular} & $\begin{array}{r}15 \\
17 \\
12 \\
13 \\
18 \\
12 \\
9 \\
19 \\
12\end{array}$ & $\begin{array}{l}2660 \\
3190 \\
2300 \\
2480 \\
2725 \\
3480 \\
2640 \\
2330 \\
2120 \\
2090 \\
5070 \\
3740 \\
3010\end{array}$ & $\begin{array}{l}-4.3 \\
+27.1 \\
+2.2 \\
-15.3 \\
-12.5 \\
+20.0 \\
+9.3 \\
-19.6 \\
-11.7 \\
-3.3 \\
+54.3 \\
+59.8 \\
+2.3\end{array}$ & \begin{tabular}{|r|}
1770 \\
1200 \\
1430 \\
2370 \\
1420 \\
1810 \\
1110 \\
1740 \\
1260 \\
1530 \\
1300 \\
810 \\
1270
\end{tabular} & $\begin{array}{r}-18.5 \\
-27.9 \\
-4.6 \\
0 \\
-41.8 \\
-16.0 \\
-31.0 \\
-23.5 \\
-21.2 \\
+6.3 \\
-50.3 \\
-44.8 \\
-45.3\end{array}$ & $\begin{array}{l}4430 \\
4390 \\
3730 \\
4850 \\
4145 \\
5290 \\
3750 \\
4070 \\
3380 \\
3620 \\
6370 \\
4550 \\
4280\end{array}$ & $\begin{array}{r}-11.0 \\
+5.2 \\
-0.5 \\
-8.5 \\
-25.3 \\
+2.2 \\
-7.0 \\
-21.3 \\
-15.5 \\
+0.6 \\
+8.4 \\
+16.7 \\
-18.9\end{array}$ \\
\hline
\end{tabular}

GROUP ID-4 CABAS WTTH ACUT HEYORAHAGIC NEPHETTS

\begin{tabular}{|c|c|c|c|c|c|c|c|c|c|c|c|c|c|c|c|c|c|c|c|c|}
\hline $\begin{array}{l}341 \\
369 \\
401 \\
405\end{array}$ & $\begin{array}{l}\text { March 23, } 1938 \\
\text { September 9, } 1938 \\
\text { February 23, } 1939 \\
\text { March 19, } 1939\end{array}$ & $\begin{array}{l}\mathbf{F} \\
\mathbf{F} \\
\mathbf{M} \\
\mathbf{M}\end{array}$ & $\begin{array}{l}16 \\
14 \\
14 \\
51\end{array}$ & $\begin{array}{l}157.5 \\
158.0 \\
167.6 \\
174.0\end{array}$ & $\begin{array}{l}47.8 \\
40.9 \\
50.0 \\
49.4\end{array}$ & $\begin{array}{l}4.40 \\
2.87 \\
3.20 \\
3.50\end{array}$ & \begin{tabular}{|l|}
$\mathbf{3 4 . 8}$ \\
$\mathbf{3 5 . 7}$ \\
$\mathbf{4 3 . 1}$ \\
$\mathbf{3 3 . 8}$
\end{tabular} & $\begin{array}{r}15 \\
6\end{array}$ & $\begin{array}{l}29 \\
53\end{array}$ & $\begin{array}{l}5.6 \\
7.5 \\
\mathbf{5 . 1} \\
\mathbf{3 . 9}\end{array}$ & $\begin{array}{l}3.4 \\
4.0 \\
2.3 \\
2.0\end{array}$ & $\begin{array}{l}2.2 \\
3.5 \\
2.8 \\
1.9\end{array}$ & $\begin{array}{l}115 / 75 \\
108 / 68 \\
126 / 72 \\
162 / 72\end{array}$ & 8 & $\begin{array}{l}1680 \\
2450 \\
2860 \\
2800\end{array}$ & $\begin{array}{l}-27.2 \\
+5.8 \\
-1.4 \\
-0.1\end{array}$ & $\begin{array}{r}900 \\
1370 \\
1490 \\
1400\end{array}$ & $\begin{array}{l}-41.5 \\
-11.3 \\
-34.4 \\
-42.1\end{array}$ & $\begin{array}{l}2580 \\
3820 \\
4350 \\
4200\end{array}$ & $\begin{array}{l}-0.3 \\
=1.0 \\
-15.9 \\
-23.6\end{array}$ \\
\hline
\end{tabular}

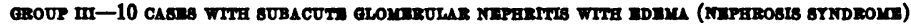

\begin{tabular}{|c|c|c|c|c|c|c|c|c|c|c|c|c|c|c|c|c|c|c|c|c|c|}
\hline $\begin{array}{r}8 \mathrm{~A} \\
8 \mathrm{~B} \\
192 \\
290 \mathrm{~A} \\
290 \mathrm{~B} \\
290 \mathrm{C} \\
290 \mathrm{D} \\
290 \mathrm{E} \\
295 \\
297 \mathrm{~A} \\
297 \mathrm{~B} \\
324 \mathrm{~A} \\
324 \mathrm{~B} \\
336 \mathrm{~A} \\
336 \mathrm{~B} \\
336 \mathrm{C} \\
336 \mathrm{D} \\
336 \mathrm{E} \\
339 \\
360 \\
367 \mathrm{~A} \\
367 \mathrm{~B} \\
367 \mathrm{C}\end{array}$ & $\begin{array}{l}\text { December 5, } 1934 \\
\text { October 19,1935 } \\
\text { June 3, 1936 } \\
\text { February 18, } 1937 \\
\text { February 26, 1937 } \\
\text { March 3, 1937 } \\
\text { March 18, 1937 } \\
\text { October 4, 1938 } \\
\text { February 26, 1937 } \\
\text { March 10, 1937 } \\
\text { October 7, 1937 } \\
\text { December 8, 1937 } \\
\text { April 12, 1938 } \\
\text { February 15, } 1938 \\
\text { February 24, 1938 } \\
\text { March 16, 1938 } \\
\text { April 2, 1938 } \\
\text { May 11, 1938 } \\
\text { March 18, 1938 } \\
\text { June 27, 1938 } \\
\text { September 7, } 1938 \\
\text { September 29, } 1938 \\
\text { February 3, } 1939\end{array}$ & $\begin{array}{l}\mathbf{M} \\
\mathbf{M} \\
\mathbf{M} \\
\mathbf{M} \\
\mathbf{M} \\
\mathbf{M} \\
\mathbf{M} \\
\mathbf{M} \\
\mathbf{M} \\
\mathbf{M} \\
\mathbf{M} \\
\mathbf{M} \\
\mathbf{M} \\
\mathbf{M} \\
\mathbf{M} \\
\mathbf{M} \\
\mathbf{M} \\
\mathbf{M} \\
\mathbf{F} \\
\mathbf{M} \\
\mathbf{M} \\
\mathbf{M}\end{array}$ & $\begin{array}{l}45 \\
45 \\
76 \\
17 \\
17 \\
17 \\
17 \\
17 \\
14 \\
20 \\
20 \\
47 \\
47 \\
19 \\
19 \\
19 \\
19 \\
19 \\
30 \\
14 \\
27 \\
27 \\
27\end{array}$ & $\begin{array}{l}168.9 \\
168.9 \\
156.0 \\
185.3 \\
185.3 \\
185.3 \\
185.3 \\
185.3 \\
160.0 \\
172.6 \\
172.6 \\
186.4 \\
186.4 \\
171.4 \\
171.4 \\
171.4 \\
171.4 \\
171.4 \\
155.0 \\
156.3 \\
179.5 \\
179.5 \\
179.5\end{array}$ & \begin{tabular}{|l|}
76.6 \\
72.0 \\
55.9 \\
73.4 \\
69.0 \\
69.0 \\
71.2 \\
67.0 \\
45.0 \\
69.5 \\
61.3 \\
89.8 \\
95.4 \\
87.6 \\
81.4 \\
66.6 \\
55.4 \\
55.8 \\
47.6 \\
46.0 \\
68.0 \\
61.4 \\
68.0
\end{tabular} & $\begin{array}{l}3.80 \\
2.31 \\
6.05 \\
3.11 \\
3.42 \\
2.63 \\
.2 .58 \\
2.57 \\
4.20 \\
3.83 \\
3.65 \\
3.05 \\
3.34 \\
3.30 \\
2.90 \\
2.45 \\
2.89 \\
3.10 \\
2.85 \\
4.94 \\
6.01 \\
5.91 \\
5.93\end{array}$ & \begin{tabular}{|l|}
46.1 \\
27.3 \\
44.0 \\
31.1 \\
30.7 \\
32.8 \\
29.5 \\
22.1 \\
40.9 \\
32.2 \\
31.5 \\
32.3 \\
30.3 \\
23.5 \\
22.0 \\
21.1 \\
21.9 \\
26.6 \\
27.6 \\
41.1 \\
50.8 \\
53.2 \\
45.8
\end{tabular} & $\begin{array}{r}32 \\
89 \\
11 \\
11 \\
22 \\
40 \\
21 \\
53 \\
14 \\
21 \\
24 \\
43 \\
24 \\
28 \\
35 \\
36 \\
42 \\
153 \\
8\end{array}$ & $\begin{array}{l}36 \\
40 \\
68 \\
59 \\
39 \\
50 \\
54 \\
64 \\
24 \\
21 \\
22 \\
21\end{array}$ & $\begin{array}{l}4.2 \\
4.3 \\
4.5 \\
3.5 \\
3.5 \\
5.0 \\
3.4 \\
5.8 \\
3.4 \\
3.8 \\
5.6 \\
3.4 \\
3.2 \\
3.6 \\
3.6 \\
3.7 \\
4.5 \\
5.9 \\
4.3 \\
5.8 \\
3.6 \\
3.8 \\
6.4\end{array}$ & $\begin{array}{l}2.3 \\
1.8 \\
1.5 \\
2.2 \\
2.4 \\
2.5 \\
1.8 \\
3.3 \\
1.6 \\
2.3 \\
3.4 \\
0.9 \\
1.2 \\
1.5 \\
1.7 \\
1.6 \\
2.3 \\
3.2 \\
2.7 \\
1.6 \\
1.6 \\
4.8\end{array}$ & $\begin{array}{l}1.9 \\
2.5 \\
3.0 \\
1.3 \\
1.1 \\
2.5 \\
1.6 \\
2.5 \\
1.8 \\
1.5 \\
2.2 \\
2.5 \\
2.0 \\
2.1 \\
1.9 \\
2.1 \\
2.2 \\
2.7 \\
3.1 \\
2.0 \\
2.2 \\
1.6\end{array}$ & $\begin{array}{l}200 / 130 \\
180 / 100 \\
80 / 50(?) \\
160 / 110 \\
155 / 85 \\
160 / 95 \\
180 / 140 \\
170 / 110 \\
155 / 125 \\
164 / 92 \\
145 / 96 \\
160 / 88 \\
155 / 105 \\
180 / 135 \\
180 / 130 \\
155 / 110 \\
145 / 105 \\
156 / 124 \\
190 / 140 \\
110 / 84 \\
110 / 60 \\
120 / 80 \\
105 / 70\end{array}$ & $\begin{array}{r}140 \\
\\
110 \\
90 \\
105 \\
\\
70 \\
120\end{array}$ & $\begin{array}{l}25 \\
\\
19 \\
18 \\
21 \\
24 \\
19 \\
15 \\
15 \\
17\end{array}$ & \begin{tabular}{|l|}
3170 \\
3740 \\
2150 \\
3420 \\
3610 \\
3420 \\
3505 \\
4650 \\
1670 \\
3470 \\
3370 \\
3910 \\
3670 \\
3160 \\
3360 \\
3600 \\
3290 \\
3100 \\
1980 \\
2260 \\
2590 \\
2480 \\
3260 \\
\end{tabular} & $\begin{array}{r}+7.8 \\
+27.2 \\
-17.6 \\
+3.9 \\
+9.8 \\
+3.9 \\
+6.6 \\
+41.4 \\
+33.7 \\
+13.8 \\
+10.5 \\
+17.4 \\
+10.2 \\
+5.0 \\
+11.6 \\
+19.6 \\
+9.3 \\
+2.9 \\
+12.6 \\
+0.4 \\
+18.8 \\
-22.2 \\
+2.2\end{array}$ & $\begin{array}{r}2710 \\
1400 \\
1110 \\
1550 \\
1610 \\
1680 \\
1675 \\
1340 \\
1150 \\
1650 \\
1550 \\
1880 \\
1590 \\
980 \\
940 \\
970 \\
920 \\
1130 \\
760 \\
1570 \\
2690 \\
2820 \\
2740\end{array}$ & $\begin{array}{r}+17.3 \\
-39.2 \\
-20.1 \\
-40.0 \\
-30.7 \\
-35.0 \\
-35.2 \\
-48.2 \\
-41.8 \\
-31.2 \\
-35.4 \\
-31.1 \\
-39.3 \\
-58.5 \\
-60.3 \\
-59.0 \\
-61.2 \\
-52.2 \\
-49.6 \\
-11.5 \\
+7.0 \\
+12.3 \\
+5.2\end{array}$ & \begin{tabular}{|l|}
5880 \\
5140 \\
3260 \\
4970 \\
5220 \\
5100 \\
5180 \\
5990 \\
2820 \\
5120 \\
4920 \\
5790 \\
5260 \\
4140 \\
4300 \\
4570 \\
4210 \\
4230 \\
2740 \\
3830 \\
5280 \\
5300 \\
6000
\end{tabular} & $\begin{array}{l}+10.7 \\
-2.1 \\
-17.4 \\
-15.4 \\
-11.1 \\
-13.2 \\
-11.8 \\
+2.0 \\
-37.3 \\
-6.1 \\
-\quad 9.7 \\
-2.7 \\
-11.6 \\
-23.0 \\
-22.0 \\
-15.0 \\
-21.6 \\
-21.3 \\
-27.2 \\
-4.8 \\
=7.5 \\
-7.0 \\
+\quad 5.2\end{array}$ \\
\hline
\end{tabular}

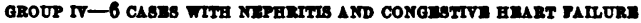

\begin{tabular}{|c|c|c|c|c|c|c|c|c|c|c|c|c|c|c|c|c|c|c|c|c|c|}
\hline $\begin{array}{l}359 \\
368 \mathrm{~A} \\
368 \mathrm{~B} \\
374 \\
380 \\
393 \\
403\end{array}$ & $\begin{array}{l}\text { June 25, } 1938 \\
\text { September 8, } 1938 \\
\text { September 27, } 1938 \\
\text { September 28, } 1938 \\
\text { October 20, } 1938 \\
\text { February 16, } 1939 \\
\text { March 6, 1939 }\end{array}$ & $\begin{array}{l}\mathbf{M} \\
\mathbf{F} \\
\mathbf{F} \\
\mathbf{F} \\
\mathbf{F} \\
\mathbf{M} \\
\mathbf{F}\end{array}$ & $\begin{array}{l}43 \\
46 \\
46 \\
61 \\
36 \\
50 \\
54\end{array}$ & $\begin{array}{l}170.0 \\
156.2 \\
156.2 \\
164.0 \\
161.3 \\
167.5 \\
165.1\end{array}$ & $\begin{array}{l}59.1 \\
71.4 \\
62.2 \\
67.2 \\
50.8 \\
58.4 \\
63.0\end{array}$ & $\begin{array}{l}\mathbf{5 . 5 0} \\
\mathbf{2 . 0 3} \\
\mathbf{2 . 3 1} \\
\mathbf{4 . 3 0} \\
\mathbf{2 . 5 5} \\
\mathbf{6 . 1 9} \\
\mathbf{5 . 0 5}\end{array}$ & $\begin{array}{l}38.9 \\
23.2 \\
20.5 \\
40.7 \\
23.3 \\
43.4 \\
43.1\end{array}$ & $\begin{array}{r}78 \\
111 \\
15 \\
36 \\
13\end{array}$ & $\begin{array}{l}47 \\
\\
\\
36 \\
59 \\
74 \\
31\end{array}$ & $\begin{array}{l}\mathbf{5 . 9} \\
\mathbf{5 . 6} \\
\mathbf{5 . 6} \\
\mathbf{7 . 5} \\
\mathbf{5 . 3} \\
\mathbf{5 . 9} \\
\mathbf{7 . 0}\end{array}$ & $\begin{array}{l}3.5 \\
3.4 \\
3.4 \\
4.2 \\
3.6 \\
2.9 \\
3.5\end{array}$ & $\begin{array}{l}2.4 \\
2.2 \\
2.2 \\
3.3 \\
1.7 \\
3.0 \\
\mathbf{3 . 5}\end{array}$ & $\begin{array}{l}190 / 120 \\
180 / 80 \\
180 / 90 \\
170 / 118 \\
178 / 104 \\
210 / 100 \\
170 / 140\end{array}$ & \begin{tabular}{|c|}
150 \\
120 \\
$(80 ?)$ \\
80 \\
135 \\
130
\end{tabular} & $\begin{array}{l}28 \\
17 \\
12 \\
18 \\
19 \\
18 \\
16\end{array}$ & $\begin{array}{l}4000 \\
3220 \\
2950 \\
2510 \\
3200 \\
3200 \\
2440\end{array}$ & $\begin{array}{r}+34.7 \\
+40.3 \\
+28.6 \\
+3.3 \\
+33.3 \\
+10.3 \\
+0.4\end{array}$ & $\begin{array}{r}2550 \\
980 \\
760 \\
1720 \\
960 \\
2450 \\
1850\end{array}$ & $\begin{array}{r}+9.5 \\
-35.9 \\
-50.3 \\
+6.2 \\
-38.0 \\
+7.7 \\
+14.2\end{array}$ & \begin{tabular}{|l|}
6550 \\
4220 \\
3710 \\
4230 \\
4160 \\
5650 \\
4290
\end{tabular} & $\begin{array}{r}+23.6 \\
+9.8 \\
+3.0 \\
+4.4 \\
+5.3 \\
+9.2 \\
+5.9\end{array}$ \\
\hline
\end{tabular}


TABLE II

Blood volume and hemodynamics in 16 cases of essential hypertension without renal involvement

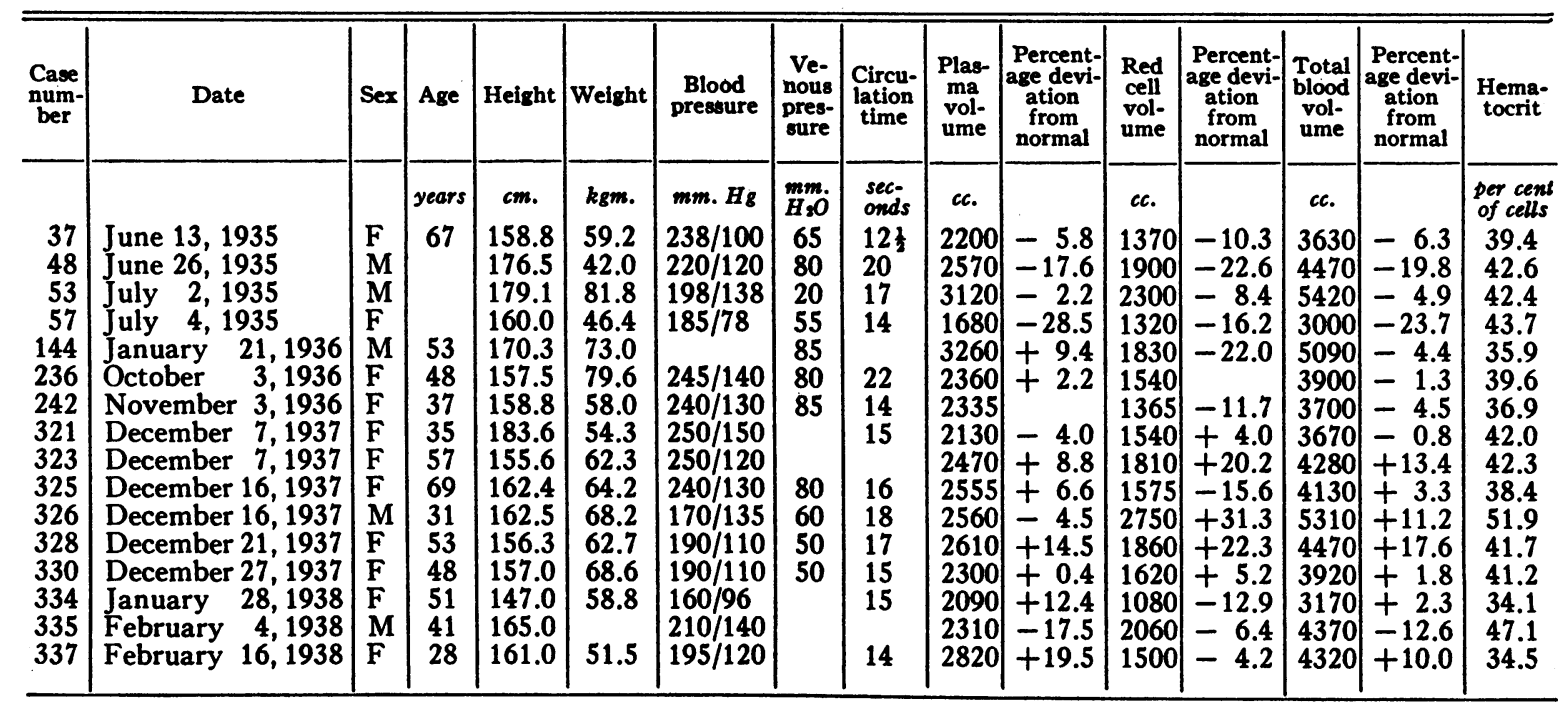

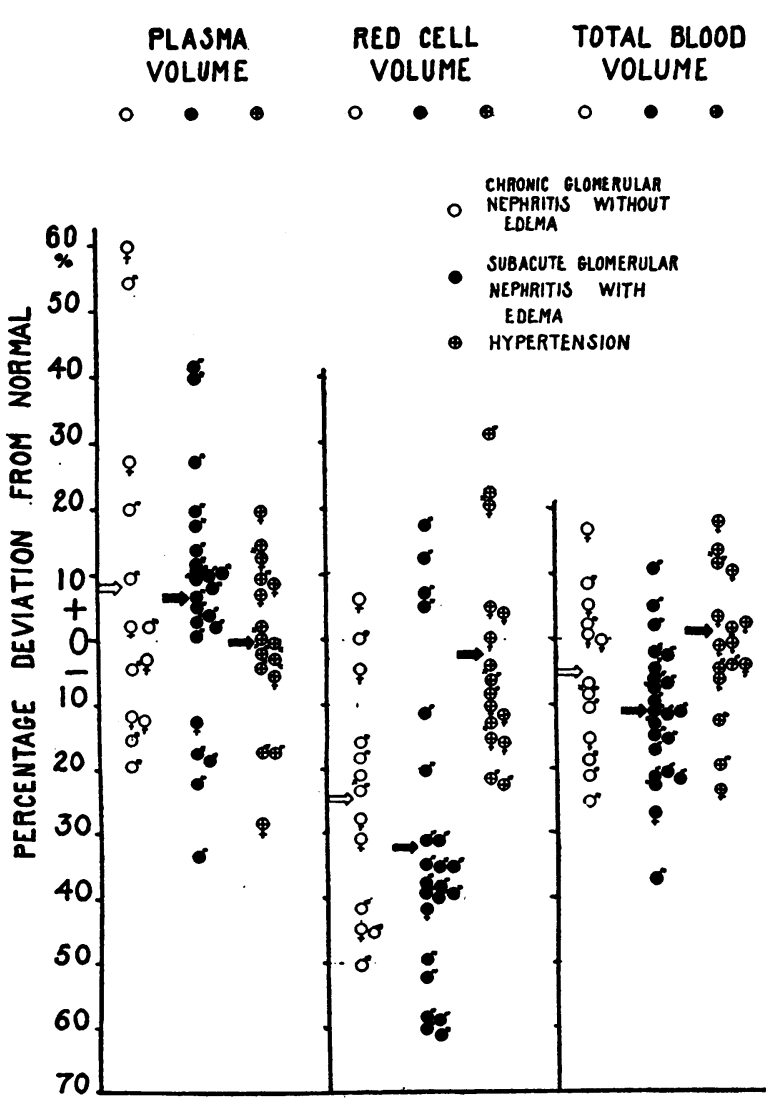

Fig. 1. Brood Volume in Bright's Disease

Case distribution in terms of percentage deviation from normal. Arrows indicate group averages. The hypertensives constitute a group with plasma, circulating red
The 4 cases with acute hemorrhagic nephritis (Group II) have subnormal circulating red cell and total blood volumes, the degree of reduction being comparable to that of Groups I and III.

The relationship of the degree of abnormality in plasma, circulating red cell, and total blood volume to the red blood cell count in Groups I to IV inclusive is shown in Figure 2. The values for Groups I, II, and III were averaged together. A definite tendency is evident for the plasma volume to increase and attain higher than normal levels and for the circulating red cell volume to decrease further below normal as the red blood cell count declines. The interrelation of these changes is such that total blood volume remains below normal in about the same degree regardless of the erythrocyte level.

Changes in the plasma, circulating red cell, and total blood volume taking place in 6 cases of subacute glomerular nephritis with edema during periods of diuresis are shown in relation to changes in body weight in Figure 3. No consistent relationship between changes in the amount

cell, and total blood volume within normal limits. In subacute and chronic nephritis the great reduction in circulating red cell volume more than offsets the elevation in plasma volume so that total blood volume is below normal, and these deviations from normal are more extreme in the edematous than in the non-edematous phases of the disease. 


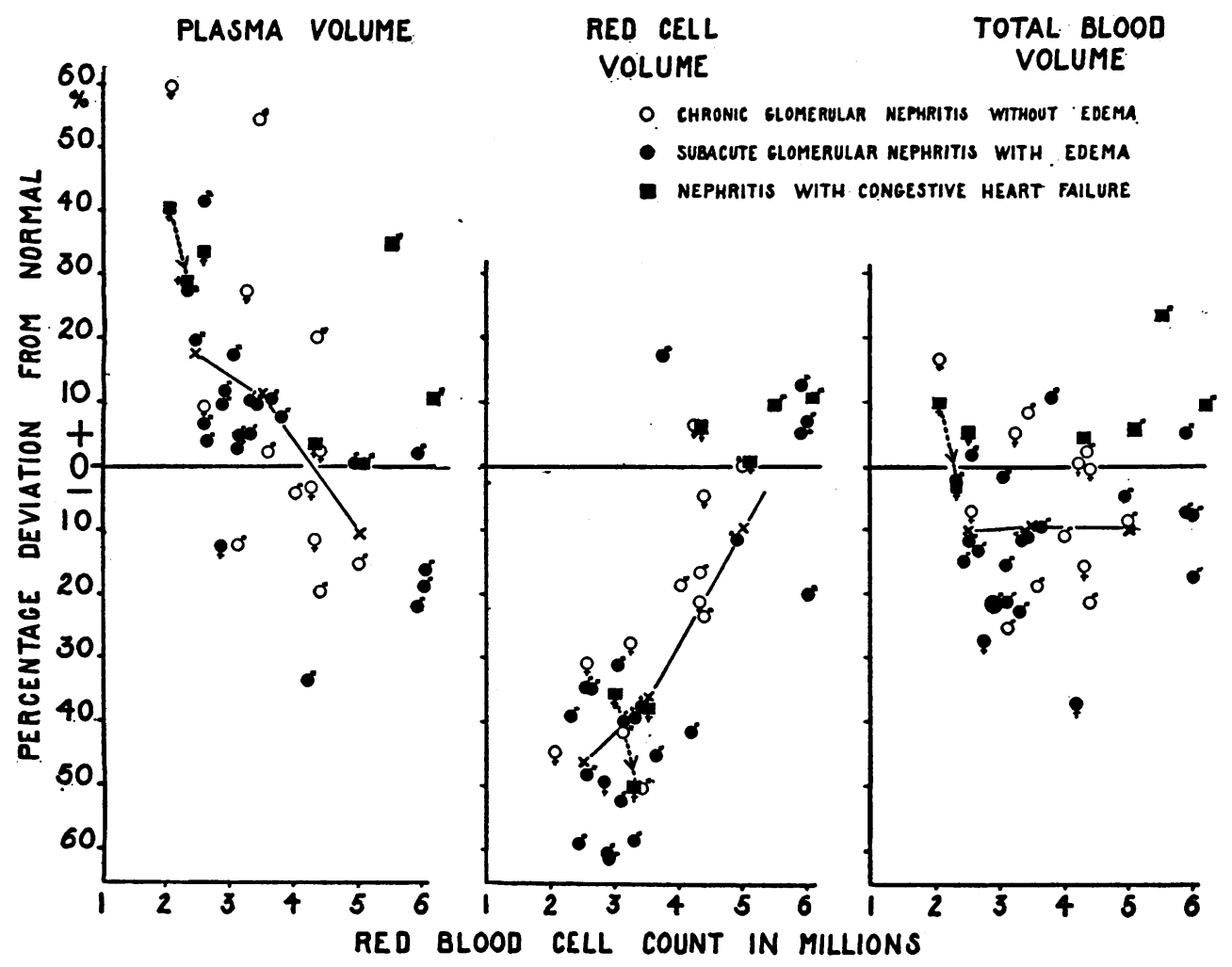

Fig. 2. Blood Volume in Relation to Erythrocyte Leved

The solid lines represent the average values for nephritics without congestive heart failure. As anemia develops in nephritis there is a progressive rise in plasma volume above and a fall in circulating red cell volume to below normal, with little change in total blood volume. The values for the cases with congestive heart failure are definitely higher than the average values for nephritics without congestive heart failure. The broken line indicates the change in volume accompanying compensation in a case with congestive heart failure.

of edema present, as evidenced by body weight and the course of either plasma or circulating red cell volume, was observed. Thus, during the period of diuresis plasma volume increased in Case 8, fluctuated, with a general tendency to increase, in Cases 290, 336, and 367, and decreased slightly in Case 297. In Case 324 during a period in which edema and body weight increased plasma volume fell. Circulating red cell volume underwent only minor changes in Cases 290, 336, and 367 in which plasma volume rose and in Case 297 in which plasma volume fell slightly, but decreased considerably in Cases 8 and 324, this change being accompanied by an increase in plasma volume in the former and a decrease in the latter case.

Figure 4 shows the circulation time in Groups I, II, III, and IV in relation to the red cell count.
While the majority of determinations were within normal limits, the average trend did not indicate an acceleration of blood flow as anemia progressed, but rather the opposite condition. Values for cases in Group IV (with congestive heart failure) were definitely above the average for the other groups.

The degree of abnormality in plasma, circulating red cell, and total blood volume found in the 6 cases in whom renal disease was accompanied by congestive heart failure (Group IV) are shown in Figure 2 in relation to similar findings in the groups without cardiac insufficiency. The significance of these results will be considered in the discussion.

\section{DISCUSSION}

A certain degree of individual variation from the averages exhibited by the various groups as 

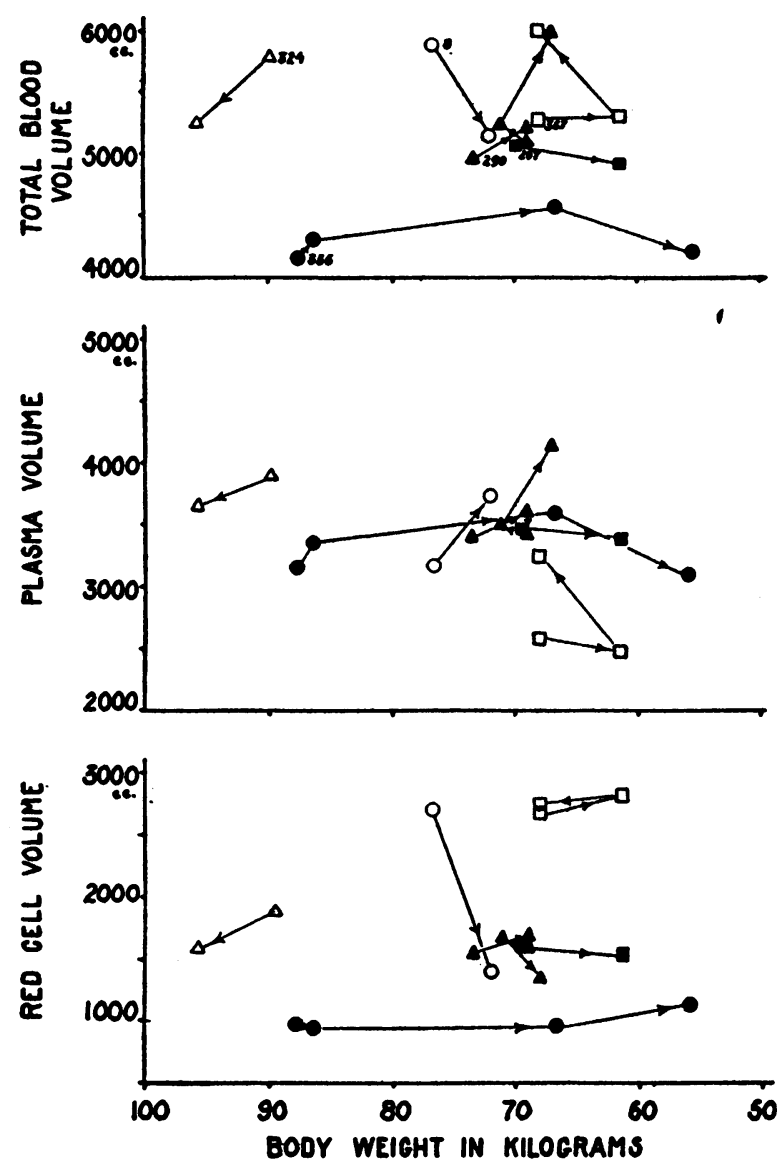

Fig. 3. Blood Volume Changes During Diuresis

Each symbol represents a case of subacute glomerular nephritis with edema (nephrosis syndrome) and corresponds to case numbers listed in Table $I$ as follows: Case $8=0$, Case $290=\Delta$, Case $297=\square$, Case $324=$ $\Delta$, Case $336=0$, and Case $367=\square$. The direction and degree of the changes in relation to changes in serum albumin, blood urea nitrogen, and erythrocyte level are discussed in the text.

a whole was encountered in this study. It must be remembered that the basis for prediction of individual normal blood volume, namely height, is of necessity an arbitrary one, and it may well be that the predicted normal volume was too high in some cases due to the cachexia of a wasting disease and too low in other cases who were in a fair state of nutrition when first studied. However, the average values of the groups as a whole represent deviations from the normal state which are truly characteristic of the disease under discussion.
Our findings are not in entire agreement with the views expressed by other investigators. The nature and magnitude of errors inherent in the early dye techniques, particularly those apt to be encountered in patients with disturbed circulations, have been commented on before (11) and may explain to some extent the general inconsistencies encountered in the literature. It would seem that the findings of a normal plasma volume $(5,9)$ and increased total blood volume $(6)$ in chronic glomerular nephritis without renal edema are in error. We also differ from Brown and Rowntree (9), who stated that in "nephrosis" (in our terminology subacute glomerular nephritis with renal edema) total blood volume was normal when the disease was uncomplicated by anemia, and higher than normal when anemia was present. The majority of our cases had subnormal total blood volumes, and as the anemia progressed, further diminution occurred. We cannot agree with Brown and Rowntree (9) in their statement that in "nephrosis" loss of edema is accompanied

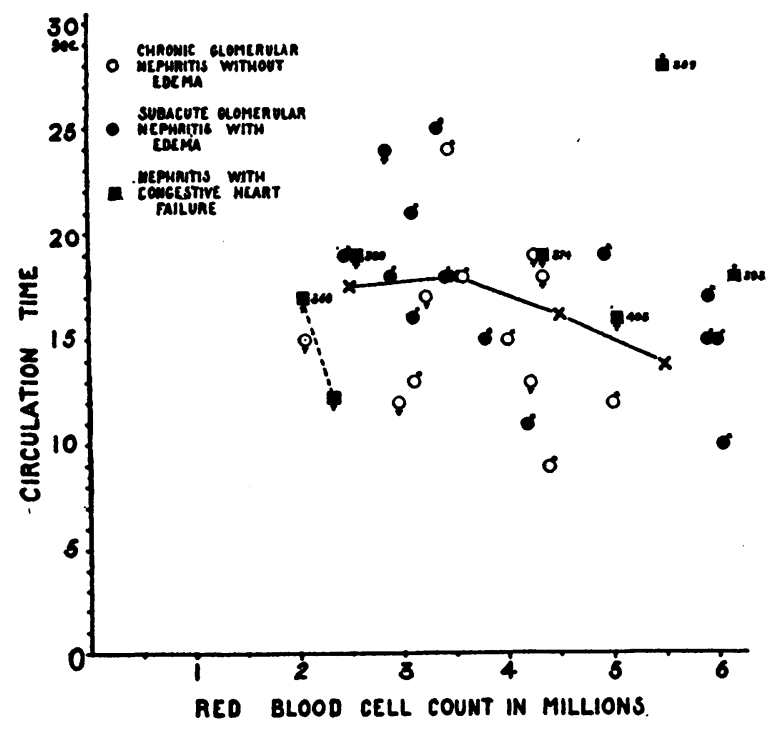

Fig. 4. Circulation Time in Bright's Disease

As anemia progresses circulation time does not become faster as it does in primary and secondary anemia, and tends to be slower in the edematous than non-edematous cases. The average trend in both types of nephritis is indicated by the solid line. In congestive heart failure circulation time is slower than in nephritis without cardiac insufficiency regardless of the degree of anemia present. The broken line indicates the change in circulation time in Case $\mathbf{3 6 8}$ during recovery from congestive heart failure. 
by no significant changes in either plasma or red cell volume, as in our cases large changes in these blood volume components were observed during periods of diuresis.

In our opinion it may be stated definitely that in subacute or chronic glomerular nephritis with or without renal edema or renal insufficiency but without congestive heart failure the plasma volume is above and the circulating red cell and total blood volume are below a normal value for that individual in a state of good health. The diminution in circulating red cell and total blood volume tends to be more severe in subacute glomerular nephritis with renal edema (nephrosis syndrome) than in glomerular nephritis without edema.

There is a tendency towards a linear relationship between the degree of elevation above normal in the plasma volume and of decrease below normal in circulating red cell volume and the red cell count in nephritis. While this relationship is not numerically identical with that found in primary (20) and secondary anemia (21), it is similar in many respects. A distinct difference in respect to total blood volume exists, however, in that in primary anemia, as the red cell count rises to 5 million under liver therapy, the total blood volume increases to normal, whereas in Bright's disease, total blood volume remains below normal regardless of the erythrocyte level. The reason for this difference is not clear from the data obtained in this study and merits further investigation. With this exception in respect to the state of the blood volume the anemia of Bright's disease presents a striking similarity to primary and secondary anemia.

Of particular interest is the relationship of the course of the plasma volume to alterations in other factors known to affect body water regulation. That these factors may alter the plasma volume in opposite direction and varying degree is strongly suggested by the data presented in Figure 3, in which it is apparent that in an individual case the loss of a given amount of edema fluid is not accompanied by a constant change in plasma volume.

Our data permit us to examine the influence of 3 factors upon the plasma volume, namely the serum albumin concentration, the blood urea nitrogen concentration, and the degree of anemia present as expressed by the red cell count. In Figure 5 the percentage abnormality in plasma volume is shown in relation to the serum albumin concentration. The average values indicate a tendency for plasma volume to increase as serum albumin increases. An identical relationship was found to exist between the plasma volume and the total serum protein concentration. In Figure 5 a similar tendency towards a direct relationship between plasma volume and blood urea nitrogen is illustrated. The increase in plasma volume accompanying a declining red cell count in both primary and secondary anemia has been commented on above and is illustrated with respect to the cases of nephritis herein studied in Figure 2.

The effect of these 3 factors on the course of the plasma volume in the 6 edematous cases followed during diuresis is summarized in Table III.

TABLE III

Theoretical and observed effect of changes in serum albumin concentration, blood urea nitrogen, and red cell count on plasma volume during diuresis

\begin{tabular}{|c|c|c|c|c|c|c|c|}
\hline \multirow{2}{*}{$\begin{array}{l}\text { Case } \\
\text { num- } \\
\text { ber }\end{array}$} & \multicolumn{2}{|c|}{ Serum albumin } & \multicolumn{2}{|c|}{$\begin{array}{l}\text { Blood ures } \\
\text { nitrogen }\end{array}$} & \multicolumn{2}{|c|}{ Rod cell count } & \multirow{2}{*}{$\begin{array}{l}\text { Obeerved } \\
\text { change in } \\
\text { plesens } \\
\text { volume }\end{array}$} \\
\hline & $\begin{array}{c}\text { Obeorved } \\
\text { ehange }\end{array}$ & $\begin{array}{l}\text { Proo } \\
\text { dieted } \\
\text { effect }\end{array}$ & $\begin{array}{l}\text { Obeerved } \\
\text { change }\end{array}$ & $\begin{array}{l}\text { Pro- } \\
\text { dietod } \\
\text { effect }\end{array}$ & $\begin{array}{c}\text { Oboerved } \\
\text { change }\end{array}$ & $\begin{array}{l}\text { Proo } \\
\text { dieted } \\
\text { effect }\end{array}$ & \\
\hline 8 & Decreased & + & Increased & + & Decreased & + & $\begin{array}{r}\infty \\
+570\end{array}$ \\
\hline 290 & $\begin{array}{l}\text { Fluctuated, } \\
\text { then } \\
\text { inereased }\end{array}$ & $t$ & Increased & + & Decreased & + & +1230 \\
\hline 297 & $\begin{array}{c}\text { Slightly } \\
\text { increaced }\end{array}$ & + & $\begin{array}{l}\text { Slightly } \\
\text { inereaced }\end{array}$ & + & $\begin{array}{l}\text { Slightly } \\
\text { decreased }\end{array}$ & + & -80 \\
\hline 821 & Inereased & + & $p$ & - & Inereased & - & -240 \\
\hline 336 & $\begin{array}{l}\text { Fluctuated, } \\
\text { then } \\
\text { inereased }\end{array}$ & + & $\begin{array}{l}\text { Increased } \\
\text { steadily }\end{array}$ & + & $\begin{array}{l}\text { Decreased, } \\
\text { then } \\
\text { increased }\end{array}$ & \pm & $\begin{array}{l}+440 \text {, late } \\
-60\end{array}$ \\
\hline 367 & Greatly & + & No change & 0 & No change & 0 & +670 \\
\hline
\end{tabular}

- Data on blood urea nitrogen not available. Nonprotein nitrogen decreased slightly.

The conformity of the observed change in plasma volume to the change predicted on the basis of the sum total effect of variations in the 3 factors is striking.

This concept of the interrelationships of 3 factors regulating the balance between plasma and extravascular fluid is in keeping with the views expressed in the literature. Since the clinical application by Epstein (22) of Starling's work (23) on the osmotic pressure of the plasma proteins, 

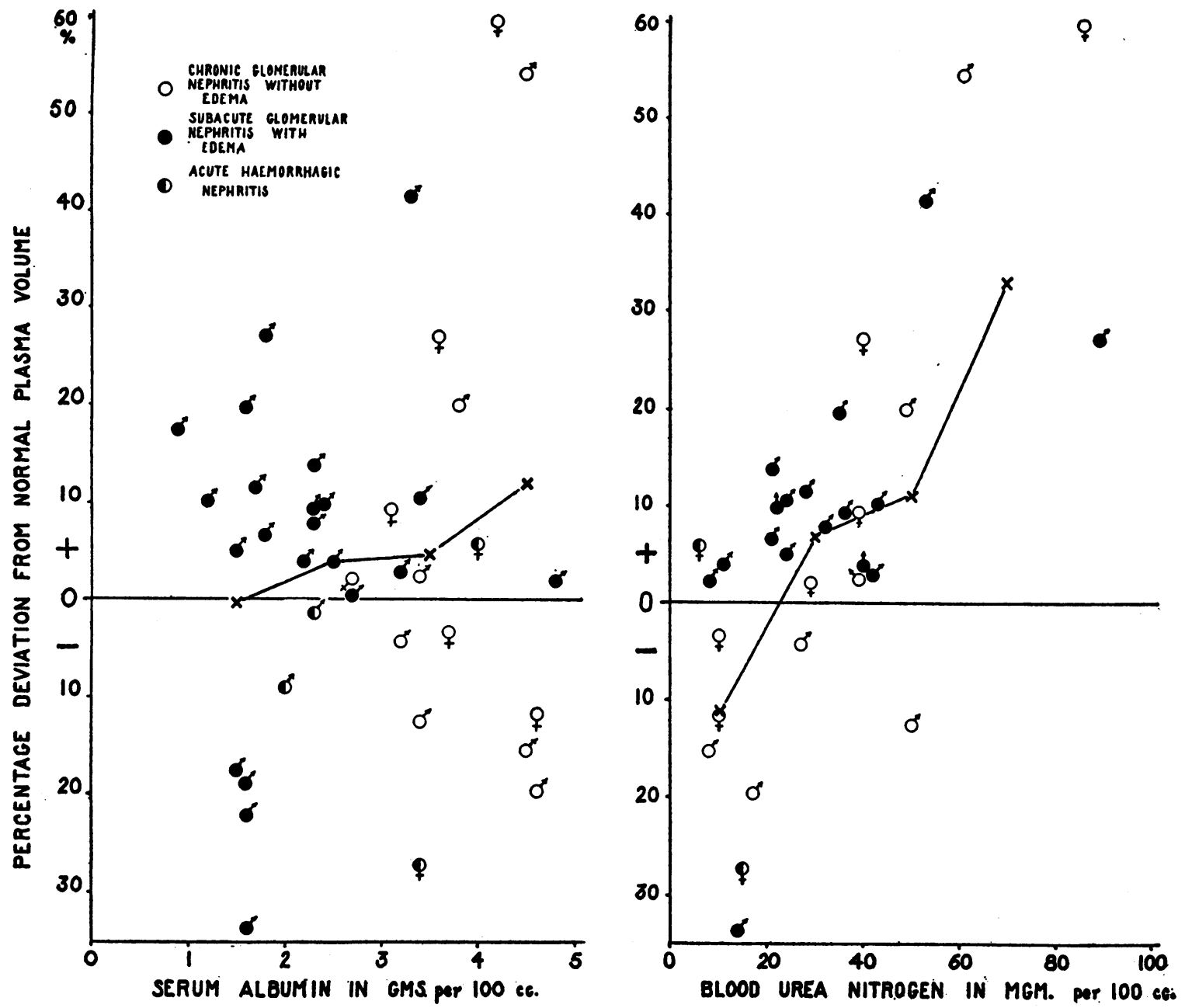

Fig. 5. Plasma Volume in Relation to Serum Albumin and Blood Urea Nitrogen

Increasing concentration of serum albumin and blood urea nitrogen is accompanied by an increase in plasma volume, the average trend of which is indicated by the solid lines.

much evidence has accumulated to establish the connection between albuminuria, low plasma protein concentration, decreased osmotic pressure of the plasma, and the development of edema in nephritis (24 to 32 ). On the basis of present knowledge it is to be expected that the watery element of the blood should be low in hypoproteinemia and that in edematous patients the plasma volume should increase as the serum protein concentration rises under therapy, providing the electrolyte balance remains unaltered. While determinations of blood electrolytes were not made in this study, in our cases of nephritis (see Figure 5) as the nonprotein nitrogen concentration rose, the plasma volume tended to rise. The mechanism of this augmentation of the plasma volume is not clear.

The work of Blumgart et al. (34) has shown that in anemia the circulation time becomes faster as the red cell count diminishes. It is interesting that a similar trend was not encountered in the cases of Bright's disease herein studied. The majority of our cases had moderate to severe anemia, and yet the average circulation as shown in Figure 4 did not definitely become faster as the average red cell count diminished. It is perhaps significant that the circulation time in the cases with subacute glomerular nephritis with edema (nephrosis syndrome) was, for comparable levels of anemia, slower than the group with chronic 
glomerular nephritis. The lowered basal metabolism that obtains in nephrotic cases is well known. The circulation time is slow in myxedema $(35,36)$ even when uncomplicated by anemia. In our opinion the depressed metabolism of the nephrotic cases probably accounts for the relatively slow blood flow at the levels of anemia exhibited by these patients.

There remain for final consideration those cases with renal insufficiency who were in congestive heart failure. In spite of the fact that these patients were moderately dehydrated and cachectic in the later stages of their progressive disease, conditions in which one would expect to find a hypovolemia, total blood volume was well above normal limits and considerably higher than the average of either Groups I or II. Circulating red cell volume was above normal in Cases 359, 374 , and 393 , all of whom had chronic vascular nephritis and had never progressed to the stage of azotemia and anemia, which was however the clinical condition preceding congestive failure in Cases 368 and 380. In these latter 2 cases, despite their anemia, circulating red cell volume was definitely above the average level found at a corresponding red blood cell count in the nephritics without congestive failure. The elevation above normal total blood volume was not as great as the average increase above normal in congestive heart failure due to valvular disease or chronic myocarditis (37).

\section{SUM MARY}

In this study we have observed the course of the plasma and total blood volume in nephritis. Three factors appear to be concerned in the regulation of the plasma volume: serum albumin concentration, nonprotein nitrogen concentration, and the degree of anemia. The effect of these factors has been described. Regardless of the stage of the disease, whether acute, subacute, or chronic, with or without edema or renal insufficiency, the level of the plasma volume reflects the interrelationship of these 3 factors. The relationship of the changes in plasma and circulating red cell volume is such that the total blood volume always remains below normal.

With development of congestive heart failure, regardless of the degree of anemia present, an additional factor appears to be introduced resulting in an increased circulating red cell volume and hence, increased total blood volume.

\section{CONCLUSIONS}

1. In Bright's disease plasma volume tends to vary directly with the serum albumin concentration and blood nonprotein nitrogen concentration and indirectly with the degree of anemia present.

2. In the edematous stage hypoproteinemia tends to diminish, and, if present, anemia tends to augment the plasma volume.

3. During diuresis there is a tendency for plasma volume to increase chiefly in relation to the increase in the albumin fraction of the serum protein.

4. The interrelationship of changes in plasma and circulating red cell volume is such that total blood volume is below normal in all stages of the disease.

5. When congestive heart failure occurs in patients with chronic nephritis, plasma, circulating red cell, and total blood volume are definitely above average levels found at comparable levels of anemia in patients with chronic nephritis but without congestive heart failure.

6. Circulation time in the group of cases exhibiting subacute glomerular nephritis with edema (nephrosis syndrome) was slower than in the group with chronic nephritis without edema. The lowered metabolism characteristic of the former group may explain this paradoxical finding.

\section{BIBLIOGRAPHY}

1. Bright, R., Cases and observations of renal disease accompanied with the secretion of albuminous urine. Guy's Hospital Reports, 1836, 1, 338.

2a. Plesch, J., Hamodynamische Studien. Ztschr. f. exper. Path. und Therap., 1909, 6, 459.

b. Plesch, J., Untersuchungen uber die Physiologie und Pathologie der Blutmenge. Ztschr. f. klin. Med., 1922, 93, 260.

3. Schmidt, W., Blutmengen-Bestimmungen bei Nierenund Herzkrankheiten. Ztschr. f. d. ges. exper. Med., 1927, 58, 276.

4. Waterfield, R. L., Changes in blood volume in patients with edema of renal origin. J. Clin. Invest., 1931, 9, 589.

5. Linder, G. C., Lundsgaard, C., Van Slyke, D. D., and Stillman, E., Changes in the volume of plasma and absolute amount of plasma proteins in nephritis. J. Exper. Med., 1924, 39, 921. 
6. Hartwich, A., and May, G., Blutmengenbestimmungen mittels der Farbstoffmethode. Ztschr. f. d. ges. exper. Med., 1926, 53, 677.

7. Litzner, S., Experimentelle und Klinische Untersuchungen uber das Verhalten der Blutmenge bei Nierenerkrankungen. Ztschr. f. Klin. Med., 1930, 112, 93.

8. Rusznyak, S., Untersuchungen zur Frage der Gesamtblutmenge des Menschen unter normalen und pathologischen Verhältnissen. Deutsches Arch. f. klin. Med., 1927, 158, 98.

9a. Brown, G. E., and Rowntree, L. G., The volume and composition of the blood and the changes incident to diuresis in cases of edema. Arch. Int. Med., $1925,35,129$.

9b. Brown, G. E., and Rowntree, L. G., Blood volume in edema of glomerular nephritis and nephrosis. Arch. Int. Med., 1929, 41, 44.

9c. Brown, G. E., Rowntree, L. G., and Roth, G. M., The Volume of the Blood and Plasma in Health and Disease. W. B. Saunders, Philadelphia, 1929.

10. Darrow, D. C., The blood volume in cases of nephritis with edema and low serum protein concentration. Proc. Soc. Exper. Biol. and Med., 1926, 23, 740.

11. Gibson, J. G., 2d, and Evans, Wm. A., Jr., Clinical studies of the blood volume. I. Clinical application of a method employing the azo dye "Evans Blue" and the spectrophotometer. J. Clin. Invest., 1937, 16, 301.

12. Christian, H. A., Clinical varieties of nephritis. Interstate Postgraduate Medical Assembly of N. A., 1931, 71-74.

13. Evans, W. A., Venous pressure. New England J. Med., 1932, 207, 1934.

14. Winternitz, M., Deutsch, J., and Brüll, Z., Eine Klinisch brauchbare Bestimmungsmethode der Blutumlaufszeit mittels Decholininjektion. Med. Klin., 1931, 27, 986.

15. Osgood, E. E., Haskins, H. D., and Trotman, F. E., A simplification of the Osgood-Haskins hemoglobin method. J. Lab. and Clin. Med., 1931, 16, No. 5.

16. Van Slyke, D. D., and Cullen, G. E., The determination of urea by the urease method. J. Biol. Chem., 1916, 24, 117.

17. Folin, O., Laboratory Manual of Biological Chemistry. D. Appleton-Century Co., New York, 1934.

18. Koch, F. C., and McMeekin, T. L., A new direct nesslerization micro-kjeldahl method and a modification of the Nessler-Folin reagent for ammonia. J. Am. Chem. Soc., 1924, 46, 2066.

19. Gibson, J. G., 2d, and Evans, W. A., Jr., Clinical studies of the blood volume. II. Relation of plasma and total blood volume to venous pressure, blood velocity rate, physical measurements, age and sex in ninety normal humans. J. Clin. Invest., 1937, 16, 317.

20. Gibson, J. G., 2d, Clinical studies of the blood volume. VI. Changes in blood volume in pernicious anemia in relation to the hematopoietic response to intramuscular liver therapy. J. Clin. Invest., 1939, 18, 401.

21. Gibson, J. G., 2d, Harris, A. W., and Swigert, V. W., Clinical studies of the blood volume. VIII. The blood volume in secondary anemia and polycythemia vera. (In preparation.)

22. Epstein, A. A., Concerning the causation of edema in chronic parenchymatous nephritis; method for its alleviation. Am. J. M. Sc., 1917, 154, 638.

23. Starling, E. H., The physiological factors involved in the causation of dropsy. Lancet, 1896, 1, 1407.

24. Krogh, A., The Anatomy and Physiology of the Capillaries. New Haven, 1924.

25. Moore, N. S., and Van Slyke, D. D., The relationships between plasma, specific gravity, plasma protein concentration and edema in nephritis. J. Clin. Invest., 1929-30, 8, 337.

26. Barker, M. H., and Kirk, E. J., Experimental edema (nephrosis) in dogs in relation to edema of renal origin in patients. Arch. Int. Med., 1930, 45, 319.

27. Shelburne, S. A., and Egloff, W. C., Experimental edema. Arch. Int. Med., 1931, 48, 51.

28. Leiter, L., Nephrosis. Medicine, 1931, 10, 135.

29. Chang, H. C., Plasma protein and blood volume. Proc. Soc. Exper. Biol. and Med., 1931, 29, 829.

30. Lepore, M. J., Relation of plasma volume to plasma protein concentration. Proc. Soc. Exper. Biol. and Med., 1932-33, 30, 268.

31. Krogh, A., Landis, E. M., and Turner, A. H., The movement of fluid through the human capillary wall in relation to venous pressure and to the colloid osmotic pressure of the blood. J. Clin. Invest., $1932,11,63$.

32. Melnick, D., and Cowgill, G. R., The serum protein complex as a factor in regulating blood volume. Proc. Soc. Exper. Biol. and Med., 1936-37, 35, 312.

33. Weech, A. A., The significance of the albumin fraction of serum. Bull. New York Acad. of Med., $1939,15,63$.

34. Blumgart, H. L., Gargill, S. L., and Gilligan, D. R., Studies on velocity of blood flow. XV. The velocity of blood flow and other aspects of the circulation in patients with "Primary" and secondary anemia and in two patients with polycythemia vera. J. Clin. Invest., 1930, 9, 679.

35. Blumgart, H. L., Gargill, S. L., and Gilligan, D. R., Studies on velocity of blood flow. XIV. The circulation in myxedema with a comparison of the velocity of blood flow in myxedema and thyrotoxicosis. J. Clin. Invest., 1930, 9, 91.

36. Gibson, J. G., 2d, and Evans, W. A., Jr., Clinical studies of the blood volume. III. Changes in blood volume, venous pressure and blood velocity rate in chronic congestive heart failure. J. Clin. Invest., $1937,16,851$.

37. Gibson, J. G., 2d, and Harris, A. W., Clinical studies of the blood volume. V. Hyperthyroidism and myxedema. J. Clin. Invest., 1939, 18, 59. 